"la Caixa" Chair of Corporate Social

Working Paper

m:i IESE

Responsibility and Corporate Governance

WP no 656

October, 2006

University of Navarra

\title{
THE UNITED NATIONS CONVENTION AGAINST CORRUPTION AND ITS IMPACT ON INTERNATIONAL COMPANIES
}

\author{
Antonio Argandoña*
}




\title{
THE UNITED NATIONS CONVENTION AGAINST CORRUPTION AND ITS IMPACT ON INTERNATIONAL COMPANIES
}

\author{
Antonio Argandoña*
}

\begin{abstract}
Corruption is a serious economic, social, political and moral blight, especially in many emerging countries. It is a problem that affects companies in particular, especially in international commerce, finance and technology transfer. And it is becoming an international phenomenon in scope, substance and consequences. That is why, in recent years, there has been a proliferation of international efforts to tackle the problem of corruption. One such international cooperative initiative is the United Nations Convention against Corruption, signed in 2003, which came into force in December 2005. This is the first truly global instrument to prevent and combat corruption, built on a broad international consensus. The purpose of this article is to explain the origin and content of the Convention, what it adds to existing international instruments for combating corruption, and its strengths and weaknesses, mainly from the point of view of companies.
\end{abstract}

* Professor of Economics, "la Caixa" Chair of Corporate Social Responsibility and Corporate Governance, IESE

Keywords: Bribery, Convention against corruption, Corruption, Extortion, International business, United Nations. 


\section{THE UNITED NATIONS CONVENTION AGAINST CORRUPTION AND ITS IMPACT ON INTERNATIONAL COMPANIES.}

\section{Introduction ${ }^{1}$}

Corruption is a serious economic, social, political and moral blight, especially in many emerging countries. It is a problem that affects companies in particular, especially in international commerce, finance and technology transfer. ${ }^{2}$ The economic effects of corruption are well known: it leads to inefficient use of resources; it discourages productive investment, above all foreign investment; it hampers economic growth and erodes the standard of living; it unfairly redistributes wealth and income to the detriment of the poor; it inflates public spending, makes the tax system less efficient and swells the public deficit; it destabilizes national budgets, encourages capital flight and creates perverse incentives that stimulate income-seeking rather than productive activities, in a negative-sum game.

The social and political effects of corruption are no less pernicious: it undermines the rule of law and democracy; it endangers good government, efficient public administration and sound corporate governance; it distorts the markets; it threatens fundamental human rights and subverts the institutions that guarantee stability, security and sustainable development. Also, corruption tends to spread, from one agency to the next and from one company to the next, reaching out towards organized crime, mafias and money laundering. ${ }^{3}$

From the ethical point of view, corruption is a violation of vital principles of social and economic life. It gives rise to negative learning that makes its diffusion particularly insidious and the task of preventing and combating it more difficult.

\footnotetext{
* Presented to the 19th Annual Conference of the European Business Ethics Network, EBEN "Ethics in and of Global Organizations", Vienna, Austria, September $21^{\text {st }}-23^{\text {rd }}, 2006$.

${ }^{1}$ This study is part of the work of the "la Caixa" Chair of Corporate Social Responsibility and Corporate Governance at IESE. I would like to thank Cristina Carrasquero for helping with information search and selection.

${ }^{2}$ Cf. Amundsen (1999), Argandoña (2000, 2001), Elliott (1997), Jain (1998), Rose-Ackerman (1999), Tanzi (1998).

${ }^{3}$ On the relationship between corruption and money laundering, see Carlson (2000).
} 
Above all, corruption is becoming an international phenomenon in scope, substance and consequences. ${ }^{4}$ Forms of corruption are imitated and transferred from one country to another. Because corrupt behavior is illegal, the proceeds of corruption often are transferred abroad, leading to international disputes involving companies (particularly banks) in different countries. Governments, international agencies, non-governmental organizations, aid donors and transnational corporations are naturally concerned about global aspects of corruption, ranging from the spread of criminal networks to the creation of unfair conditions for trade and finance.

That is why, in recent years, there has been a proliferation of international efforts to tackle the problem of corruption. It is assumed that it is up to national governments to prevent and combat corruption in their own country. But broad-based international cooperation is needed to ensure that the measures adopted in different countries are consistent and fair and foster international relations and economic efficiency; to create an equitable framework for international relations; and also to ensure that governments have the means to tackle their national problems, which often they lack.

One such international cooperative initiative is the United Nations Convention against Corruption, signed in 2003, which came into force in December 2005. This is the first truly global instrument to prevent and combat corruption, built on a broad international consensus. The purpose of this article is to explain the origin and content of the Convention, what it adds to existing international instruments for combating corruption, and its strengths and weaknesses, mainly from the point of view of companies. In the following section we explain how the initiative developed in the context of the other anti-corruption measures adopted by international organizations. The core of the article consists of an explanation of the main points of the Convention, considered specifically from the point of view of companies operating in world markets. We then discuss the Convention's strengths and weaknesses, ending with the conclusions.

\section{Historical background ${ }^{5}$}

The United Nations Convention against Corruption is one of a set of anti-corruption initiatives taken by international bodies over the last few years. ${ }^{6}$ Exhibit 1 gives a brief overview of the international legal instruments adopted to date, and Exhibit 2 summarizes the main recommendations and other documents on the subject of corruption. ${ }^{7}$ Added to these, are other United Nations initiatives adopted in ordinary meetings of the General Assembly ${ }^{8}$ and at

\footnotetext{
${ }^{4}$ Cf. Glynn et al. (1997), Posada (2000), Rose-Ackerman (1997).

${ }^{5}$ Cf. "Report of the Ad Hoc Committee for the Negotiation of a Convention against Corruption on the work of its first to seventh sessions", United Nations, General Assembly, A/58/422, October $7^{\text {th }}, 2003$. Reports on the previous sessions of the Ad Hoc Committee have also been published. Also, see Babu (2006), Vlassis (2002), Webb (2005).

${ }^{6}$ For a summary of some of these initiatives, see Babu (2006) and Webb (2005).

${ }^{7}$ Cf. "Existing international legal instruments, recommendations and other documents addressing corruption. Report of the Secretary General”, Economic and Social Council of the United Nations, E/CN.15/2001/3, April 2 ${ }^{\text {nd }}, 2001$.

${ }^{8}$ Cf., for example, resolutions 54/205 of 22 December 1999, 55/25 of 15 November 2000, 56/186 of 21 December $2001,57 / 244$ of December $20^{\text {th }} 2002$, 58/205 of December $23^{\text {rd }} 2003,59 / 242$ of December $22^{\text {nd }} 2004$ and $60 / 207$ of December $22^{\text {nd }} 2005$.
} 
international conferences such as Monterrey $^{9}$ and Johannesburg, ${ }^{10}$ along with numerous initiatives by other public and private international organizations. ${ }^{11}$

The United Nations has been working on the prevention and eradication of corruption for a couple of decades. ${ }^{12}$ The Convention against Corruption grew out of the "Vienna Declaration", adopted by the 10th UN Congress on the Prevention of Crime and the Treatment of Offenders, held in April 2000, and the preparatory work for the UN Convention against Transnational Organized Crime. ${ }^{13}$ In December 1999, the General Assembly directed the Ad Hoc Committee on the Elaboration of a Convention against Transnational Organized Crime to incorporate into the draft convention measures against corruption linked to organized crime, including provisions regarding the sanctioning of acts of corruption involving public officials, either in the form of an annex to said convention or as a separate instrument. ${ }^{14}$

One year later, the United Nations General Assembly decided that it was desirable to have an international legal instrument against corruption independent of the UN Convention against Transnational Organized Crime. ${ }^{15}$ Shortly afterwards, the General Assembly invited the intergovernmental open-ended expert group convened for that purpose to examine also the question of illegally transferred funds and the repatriation of such funds to their countries of origin. ${ }^{16}$ And in January 2002 it decided that the Ad Hoc Committee should negotiate a "broad and effective" convention, adopting a "comprehensive and multidisciplinary" approach that could be approved before the end of 2003. ${ }^{17}$

The Ad Hoc Committee for the negotiation of the Convention met officially for the first time in Buenos Aires, from December $4^{\text {th }}$ to $7^{\text {th }}, 2001$. Between January 2002 and October 2003, seven official sessions were held in Vienna, at the headquarters of the UN Office on Drugs and Crime (UNODC), with the participation of representatives of the States Parties ${ }^{18}$ and observers from various agencies, research institutes, specialized UN bodies and other governmental and nongovernmental organizations. On 21 June 2002 a one-day technical seminar was held to discuss technical problems relating to asset recovery.

9 Cf. "Report of the International Conference on Financing for Development”, Monterrey, Mexico, March $18^{\text {th }}-22^{\text {nd }}$, 2002.

${ }^{10}$ Cf. "Report of the World Summit on Sustainable Development", Johannesburg, South African Union, August $26^{\text {th }}$ - September $4^{\text {th }} 2002$.

11 Such as the Extractive Industries Transparency Initiative (2002), the Equator Principles for Financial Institutions (2005), the Wolfsberg Anti-Money-Laundering Principles for Private Banking (2000), the FIDIC Code of Ethics and Business Integrity Management System of the International Federation of Consulting Engineers, and the Sustainable Development Charter of the International Council on Mining and Metals (2002). There are also instruments to help companies organize themselves against corruption; for example, the ICC Rules of Conduct to Combat Extortion and Bribery (published by the International Chamber of Commerce in 1977 and revised on various occasions, the last time in 2005), the Business Principles for Countering Bribery (Transparency International), the World Economic Forum's Partnership against Corruption Initiative (launched in January 2004), the OECD Guidelines for Multinational Enterprises (revised in 2000), etc. See also Vincke and Heimann (2003).

12 Examples of actions include the Code of Conduct for Law Enforcement Officials (1979), the Manual of Practical Measures against Corruption (1990), the Basic Principles on the role of Lawyers (1990), the International Code of Conduct for Public Officials (1996) and the Declaration on Crime and Public Security (1996). Cf. Babu (2006).

${ }^{13}$ Resolution 55/25, Annex II; which came into force on September 192003.

14 Resolution 54/128, of December $17^{\text {th }}, 1999$.

${ }^{15}$ Resolution 55/61, of December $4^{\text {th }}$, 2000.

${ }^{16}$ Resolution 55/188, of December $20^{\text {th }}, 2000$.

${ }^{17}$ Resolution 56/260, of January 31 $1^{\text {st }}, 2002$.

18 Between 97 and 128 States, depending on the meeting. 
The Ad Hoc Committee approved the draft Convention on October $1^{\text {st }}, 2003,{ }^{19}$ and presented it to the General Assembly, which adopted it on October $31^{\text {st }}, 2003 .^{20}$ The Convention was presented to a high-level political signing conference hosted by the government of Mexico, in Merida, on December $9^{\text {th }}-11^{\text {th }}$, 2003. On December $10^{\text {th }}, 95$ countries signed the Convention. ${ }^{21}$

To come into force, the Convention had to be ratified by at least thirty countries. Ratification implies a commitment to take whatever legislative and administrative measures are needed to make the Convention effective and give it official support. In accordance with its art. 68, the UN Convention against Corruption came into force on December $14^{\text {th }}, 2005$. By July 2006, 140 States Parties had signed the Convention and had presented the ratification instruments. ${ }^{22}$

Once the Convention comes into force, a Conference of States Parties must be called within one year "to achieve the objectives set forth in this Convention and to promote and review its implementation" (art. 63.1). Also, the States Parties must verify that their legislation is in line with what is established in the Convention and, if necessary, pass new laws or amend existing ones, create the bodies envisaged in the Convention, and endow them with the necessary means to perform their functions.

\section{Content of the Convention}

The Convention against Corruption is the first genuinely global, legally binding instrument on corruption and related matters, that is, the first to be developed with an extensive international participation and with a broad consensus of signatory States and international private sector and civil society organizations. Consequently, it must be accepted, or is expected to be accepted, by the great majority of countries in the international community, so that the fight against corruption will be seen in a new, global (as opposed to regional) perspective. This is precisely what differentiates this Convention from the other instruments available.

The purpose of the Convention is to prevent corrupt practices and illicit fund transfer, and combat these practices effectively; to criminalize and repress corrupt practices; to promote, facilitate and support international cooperation and technical assistance; to return illegally transferred funds to their countries of origin; and to promote integrity, accountability and proper management of public affairs and public property. ${ }^{23}$

The Convention is thus intended to be a comprehensive, functional and effective international instrument that takes into account the many facets of corruption and that establishes a common language and guidelines to unify international legislation in this area, with the right balance of prevention and prosecution. At the same time, the Convention acknowledges certain fundamental limitations in its approach and content, namely, the recognition of State sovereignty; the inevitable and legitimate legal, cultural, social and political differences between States Parties; and their different levels of economic development.

\footnotetext{
19 Report A/58/422 and Annex.

20 Resolution 58/4 of October $31^{\text {st }}, 2003$, and Annex. To promote the fight against corruption, it was agreed that December $9^{\text {th }}$ would be “International Anti-Corruption Day" (Resolution 58/4 of October $31^{\text {st }}, 2003$, no. 7).

${ }^{21}$ The signature we are referring to is not the deposit of the instrument of ratification of the Convention. Kenya was the first country to sign and at the time of signing also deposited the instrument of ratification.

${ }^{22}$ Verified at the UN Office on Drugs and Crime's web site on July $5^{\text {th }}$, 2006. At that date, it is significant that only a small number of advanced countries had ratified their signature: Austria, Finland, France, Latvia, Slovakia, Spain and the United Kingdom, from the European Union, plus Norway and Australia.

${ }^{23}$ Cf. art. 1.
} 
The Convention does not contain a list of the legal and moral principles that inspire it. Nevertheless, its articles contain references to the principles of proper management of public affairs and public property (art. 7) ${ }^{24}$ integrity, transparency, responsibility and accountability (arts. 7 and 10); rule of law, equality before the law, equity, independence of the judiciary (art. 11); due process of law in criminal proceedings and in civil or administrative proceedings; presumption of innocence (art. 30); recognition of sovereign equality and territorial integrity of States (art. 4) and non-intervention in the domestic affairs of other States (art. 4), etc.

The Convention consists of a preamble and 71 articles, grouped in eight chapters (see Exhibit 3).

In what follows there is no attempt to explain the whole of the document, only some of the more important aspects. First we shall discuss definitions, before moving on to preventive measures, the criminalization of corruption, international cooperation and asset recovery, paying particular attention to the behavior of companies and other private organizations.

\section{Definitions}

Some of the States that submitted proposals for the draft Convention wanted to have clear and rigorous definitions established for the most important terms. This was done only in part. ${ }^{25}$

First, it was decided that the text of the Convention would not include a definition of corruption, as this is a polyvalent and changeable term that means different things to different people, and above all because it is an evolving concept. ${ }^{26}$ In other parts of the Convention there are definitions of some of the main types of corruption, such as bribery (active) and extortion (passive bribery), both of public officials ${ }^{27}$ (art. 15) and in the private sector (art. 21), embezzlement, misappropriation of funds and other diversion of property (arts. 17 and 22), trading in influence (art. 18), abuse of functions (art. 19) and illicit enrichment (art. 20). The authors of the Convention preferred to offer this broad spectrum of offences, rather than a definition of corruption, so as to allow greater flexibility for future implementations and interpretations.

A "public official" is defined as: "(i) any person holding a legislative, executive, administrative or judicial office [...], whether appointed or elected, whether permanent or temporary, whether paid or unpaid [...]; (ii) any other person who performs a public function, including for a public agency or public enterprise, or provides a public service, as defined in the domestic law of the State Party [...]; (iii) any other person defined as a 'public official' in the domestic law of a State Party" (art. 2, a). ${ }^{28}$

\footnotetext{
24 This includes, for example, establishing objective criteria of merit, equity and aptitude in the selection, hiring, remuneration and promotion of public officials (art. 7).

25 It seems a good thing that the Convention should contain clear and precise definitions in order to unify terminology and the interpretation of terms in the different national legislations.

${ }^{26}$ Some countries proposed definitions of "corruption"; see, for example, Peru's proposal to the Preparatory Meeting of the Ad Hoc Committee for the Negotiation of a Convention against Corruption, A/AC.261/IPM/11, November $12^{\text {th }}$, 2001, no. 6, 2 and 3, and the Philippines' proposal, A/AC.261/IPM/24, of December $7^{\text {th }}, 2001$, no. 4.

${ }^{27}$ Active bribery: "The promise, offering or giving, to a public official, directly or indirectly, of an undue advantage, for the official himself or herself or another person or entity, in order that the official act or refrain from acting in the exercise of his or her official duties" (art. 15, a). Passive bribery or extortion: "The solicitation or acceptance by a public official, directly or indirectly, of an undue advantage, for the official himself or herself or another person or entity, in order that the official act or refrain from acting in the exercise of his or her official duties" (art. 15, b).

28 "Foreign public official" (art. 2, b) and "official of an international public organization" (art. 2, c) are also defined.
} 
The concept of "property", for the purpose of the Convention, is broad: "assets of every kind, whether corporeal or incorporeal, movable or immovable, tangible or intangible, and legal documents or instruments evidencing title to or interest in such assets" (art. 2, d). ${ }^{29}$

\section{Preventive measures}

As explained, the Convention puts the emphasis on measures to prevent corruption from appearing in the first place (chapter II, arts. 5 to 14). It is left to each State's discretion to implement effective anti-corruption policies (art. 5) and create organizations specifically to fight corruption (art. 6). States must endeavor to ensure that their public services are subject to safeguards that promote integrity, transparency and accountability among civil servants and hiring based on efficiency and merit (art. 7). Once hired, public officials must be subject to codes of conduct (art. 8), including measures such as declarations of assets, and disciplinary measures. States must also promote transparency and accountability in public procurement and management of public finances (art. 9), and must take measures to preserve integrity in especially critical areas such as the judiciary and prosecution services (art. 11), and to prevent money laundering (art. 14). ${ }^{30}$

Art. 12 is devoted to anti-corruption measures in the private sector. It seems clear that achieving high moral and legal standards in relations with government is impossible unless companies also adopt high standards, for themselves and for their dealings with one another. Art. 12, 2 proposes measures including cooperation between law enforcement agencies and relevant private entities; instruments to safeguard the integrity of relevant private entities, such as codes of conduct; transparency; prevention of the misuse of procedures regulating private entities; prevention of conflicts of interest; and internal auditing controls, including auditing and certification procedures. The specific measures proposed in art. 12, 3 and 4, include the promotion of internationally accepted accounting and auditing standards, the prohibition of off-the-books transactions, and the disallowance of the tax deductibility of expenses that constitute bribes.

The Convention also advocates the participation of civil society in the prevention of and fight against corruption (art. 13, 1), including access to the appropriate administrative and judicial bodies (art. 13, 2), reporting to the national investigating and prosecuting authorities (art. 39, 2), and the protection of reporting persons (art. 33) and of witnesses, experts and victims (art. 32).

\section{Criminalization of corruption}

Chapter III develops the theme of criminalization and law enforcement, which, together with preventive measures, is another of the basic pillars of the Convention. The States Parties must take legislative measures to establish as criminal offences not only active and passive bribery of national public officials (art. 15), but also active bribery of foreign public officials or officials of public international organizations (art. 16, 1). Other offences that do not appear in other international instruments are mentioned: embezzlement, misappropriation and other diversion of property by a public official (art. 17), money laundering (art. 23), obstruction of justice (art.

\footnotetext{
29 Other definitions included are those of "proceeds of crime" (art. 2, e), "freezing” or "seizure" (art. 2, f), "confiscation" (art. 2, g), "predicate offence" (art. 2, h) and "controlled delivery" (art. 2, i).

${ }^{30}$ The Convention makes no reference to important measures for the correct functioning of the preventive policies, such as press freedom or the existence of an effective democracy, probably because of their political content and significance.
} 
25), and participation as an accomplice, assistant or instigator in an offence of corruption, or any attempt to commit such an offence (art. 27, 1 and 2). ${ }^{31}$

Other acts that are considered criminal offences in certain States Parties are also included in the Convention, but are not mandatory: ${ }^{32}$ solicitation or acceptance by a foreign public official of an undue advantage (art. 16, 2), trading in influence (art. 18), abuse of functions (art. 19), illicit enrichment (art. 20), concealment (art. 24) and preparation for an offence of corruption (art. 27, 3). The possibility of making bribery in the private sector $^{33}$ (art. 21) and embezzlement in the private sector (art. 22) ${ }^{34}$ criminal offences is included as an option.

Although the offences envisaged in the Convention are invariably committed by individuals, legal persons (companies, for example) often play a decisive role, both in preparing the offences and in executing them, exploiting their results and laundering the proceeds. Accordingly, art. 26 establishes that the States Parties shall adopt such measures as may be necessary to establish the criminal, civil or administrative liability of legal persons for participation in offences. The Convention also establishes that entities or persons who have suffered damage as a result of an act of corruption have the right to initiate legal proceedings against those responsible for that damage (art. 35).

\section{International cooperation, technical assistance and information exchange}

One of the main purposes of the Convention is to promote international cooperation in preventing, investigating and combating corruption and prosecuting criminals (chapter IV, arts. 43-50). It contains provisions on extradition, mutual legal assistance, joint investigations, etc., so that the guilty parties may be prosecuted in any country and cannot escape justice. Another goal is to foster technical assistance and information exchange, especially as regards States Parties with scant resources and experience in these matters (chapter VI, arts. 60-62).

\section{Asset recovery}

A "fundamental principle" (art. 51) of the Convention, and one of its main novelties compared with other similar instruments, is the right to asset recovery, set out in chapter V (arts. 51 to 59). In many cases, the money illicitly paid to public officials (or managers or employees of private organizations) is sent abroad, resulting in a drain of funds which, in some cases, can seriously affect a country's economic development. Accordingly, the Convention details the conditions, processes and means for those funds to be returned to their countries of origin. This

\footnotetext{
31 The "dual criminality" criterion, when this is a requirement for international cooperation, "shall be deemed fulfilled irrespective of whether the laws of the requested State Party place the offence within the same category of offence or denominate the offence by the same terminology as the requesting State Party, if the conduct underlying the offence for which assistance is sought is a criminal offence under the laws of both States Parties" (art. 43, 2).

${ }^{32}$ For example: "Each State Party shall adopt such legislative and other measures as may be necessary to establish as a criminal offence...” (art. 16, 2).

${ }^{33}$ In the case of private corruption, too, a distinction is made between bribery ("The promise, offering or giving, directly or indirectly, of an undue advantage to any person who directs or works, in any capacity, for a private sector entity, for the person himself or herself or for another person, in order that he or she, in breach of his or her duties, act or refrain from acting...", art. 21, a) and extortion ("The solicitation or acceptance, directly or indirectly, of an undue advantage by any person who directs or works, in any capacity, for a private sector entity, for the person himself or herself or for another person, in order that he or she, in breach of his or her duties, act or refrain from acting...”, art. 21, b).

${ }^{34}$ The opposition of some States to mandatory criminalization of private corruption was due to the fear that such legislation would be used to restrict trade and foreign investment.
} 
entailed lengthy negotiations, taking into account not only the demands of the countries that sought to recover their assets, but also the legal and procedural safeguards of the countries that had received the funds.

Chapter $\mathrm{V}$ of the Convention establishes the means to prevent and detect transfers of the proceeds of crime (art. 52) through measures affecting financial institutions (paras. 1-4) and public officials (paras. 5-6); measures for the direct recovery of property (art. 53); mechanisms for the recovery of property through international cooperation (arts. 54-56 and 58-59) and measures for the return and disposal of assets (art. 57).

Art. 57 distinguishes three different situations. 1) Embezzlement of public funds by a public official, who tries to conceal them in another country. In this case, the property clearly belongs to the State and must be returned to its rightful owner (art. 57, 3, a). 2) Proceeds of corruption, that is, property that was not stolen (in fact, was given voluntarily to the corrupt public official), but was obtained illicitly and transferred to another country. In this case, the State of origin may or may not be the victim. The Convention establishes a criterion similar to that applied in the confiscation of money from drug trafficking or other crimes: the proceeds of the crime must be returned to the State of origin when said State is able to reasonably establish its prior ownership or when it has suffered damage and is entitled to compensation (art. 57, 3, b), always taking into account the rights of bona fide third parties (art. 57, 2). 3) All other cases of confiscation, where priority consideration is to be given to returning confiscated property to the requesting State Party or to its prior legitimate owners or compensating the victims of the crime $($ art. $57,3, \mathrm{c}) .^{35}$

\section{Lights and shadows of the Convention}

The United Nations Convention against Corruption already occupies an important place in the international community's efforts to overcome the human, moral, political, economic and social problems derived from corruption. As we pointed out earlier, this is the first truly global instrument against corruption, combining prevention and criminalization, with a strong emphasis on international cooperation, and offering governments a consistent framework, so that all efforts tend in the same direction. In scope it goes beyond other similar instruments. The criminalization of extortion of public officials (art. 15), for example, considerably extends the scope of the OECD Convention.

It remains a limited instrument, however: firstly, because of the way it was drafted, with a tendency to give priority to political and economic interests, besides human, legal and moral interests $;^{36}$ and secondly, because of its content.

Indeed, the Convention imposes no obligation on signatory countries to criminalize certain acts, such as passive bribery of a foreign public official, trading in influence, abuse of public functions or illicit enrichment. It contains a number of provisions that each State Party "shall adopt", others that each State Party "shall consider adopting" (or things they "shall endeavor to

\footnotetext{
${ }^{35}$ Canada formulated a detailed proposal, considering, among other things, the three situations presented in art. 57. Cf. Canada's proposal to the Informal Preparatory Meeting of the Ad Hoc Committee for the Negotiation of a Convention against Corruption, A/AC.261/IPM/27, December $7^{\text {th }}, 2001$.

${ }^{36}$ Some governments of developed countries took a restrictive attitude, probably to avoid the problems that could arise from legal proceedings against their citizens in countries with backward legal systems and without sufficient guarantees of human rights or fair procedure.
}

8 - IESE Business School-University of Navarra 
do"), and others that they "may adopt". Also, some articles contain safeguard clauses that limit the States Parties' obligation in the event of conflict with their constitution or the fundamental principles of their legal system. This means that one of the goals of the Convention, which is to create common standards in countries' legislation, may not be achieved.

The fact that there is no obligation to make bribery and embezzlement in the private sector a criminal offence deserves special mention, because, in many countries, the line between private and public sector is blurred, especially in the context of globalization, outsourcing and privatization of state-owned companies. ${ }^{37}$ Tolerance of private corruption inevitably makes it more difficult to prevent and combat public corruption. ${ }^{38}$

Nor is it obligatory under the Convention to make corruption in political party funding a criminal offence. In fact, the whole issue is dealt with only sketchily and in passing in the text of the Convention, ${ }^{39}$ despite the fact that this is a widespread form of corruption. ${ }^{40}$ This is probably partly because of the diversity of situations in different countries when it comes to financing political campaigns and parties. ${ }^{41}$ The problem lies in how to limit politicians' power to favor donors, rather than in the fact, amount or transparency of donations as such.

The criminalization of bribery of officials of public international organizations and other related issues was left for discussion by the Conference of the States Parties to the Convention, to be held after the Convention comes into force. ${ }^{42}$

Some articles are vague and lend themselves to varied interpretations, which may create complicated situations for companies that operate in many different countries (examples include art. 18 on trading in influence; art. 20 on illicit enrichment; and art. 35 on compensation for damage). ${ }^{43}$

Another major shortcoming of the Convention is the absence of any mechanism to punish States Parties that do not fulfill their obligations under the Convention: the problem of implementation and enforcement. This is related to the absence of monitoring and surveillance mechanisms involving representatives of civil society, companies, unions, etc. ${ }^{44}$ Such mechanisms are decisive for the success or failure of an instrument such as the Convention. ${ }^{45}$

\footnotetext{
${ }^{37}$ Cf. Argandoña (2003b).

38 Webb (2005) attributes this treatment of private corruption to the opposition of the United States, which was afraid that it would open the door to legal action against U.S. managers in other countries.

39 "Each State Party shall also consider taking appropriate legislative and administrative measures [...] to enhance transparency in the funding of candidatures for elected public office and, where applicable, the funding of political parties" (art. 7, 3). The concept of the public official (art. 2) does not include those who manage political parties or work in them.

${ }^{40}$ Again it was the United States that led the opposition to the inclusion of party funding. Cf. Webb (2005).

${ }^{41}$ Cf. Argandoña (2003a).

42 Resolution 58/4, no. 6. The Conference of the States Parties is established in art. 63. The reasons for this delay have to do mainly with the privileges and immunities of the officials of these bodies and the bodies' jurisdiction and functions.

${ }^{43}$ Michael (2004) attempts to quantify the ambiguity of the various articles of the Convention, and concludes that it is very high. However, a degree of ambiguity is necessary, first in the negotiation phase to facilitate consensus, and then in the implementation phase to adapt the provisions to the peculiarities of different countries and changing circumstances.

${ }^{44}$ Various countries proposed that a monitoring system should be established: Argentina, Austria, Benin, Cameroon, Holland, Norway, etc.

${ }^{45}$ Cf. Quinones (2000).
} 
The main purpose of monitoring mechanisms is to encourage governments first to ratify the Convention and then put it into practice. This is important given the numerous political, social, economic and technical obstacles to its implementation: new laws have to be passed; the resistance of those who stand to lose from changes in the law has to be overcome; the agencies that are to enforce the new provisions need to be staffed and funded, etc. The experience of other initiatives already under way (OECD, Council of Europe, Organization of American States) has been highly positive, so the delay in implementing monitoring mechanisms in this case already indicates a lack of political will and a curb on the fight against corruption. ${ }^{46}$

The monitoring process imposes an external discipline on governments, through reports, inspector visits, and reporting and discussion sessions. It creates a forum of governments and pressure groups and allows civil society and the private sector to participate in these tasks. ${ }^{47}$ There are other possible favorable effects in the medium term, such as improvement in the quality of legislative and institutional change, increased participation by civil society (companies, business associations, unions, non-governmental organizations, media, etc.) in the fight against corruption, the recording of good practices and experiences from other countries, and the compilation of a body of case law to aid consistent interpretation of the Convention.

Given the diversity of the parties to the Convention and the attitude of some of them during the negotiations, arguing that the monitoring processes violated their sovereignty, it was particularly difficult to agree on an effective monitoring procedure that was acceptable to all. The task of supervision and monitoring will be carried out, in principle, through the Conference of States Parties to the Convention. The Conference will be held for the first time "not later than one year following the entry into force of the Convention" (art. 63, 2). One of its tasks will be to "review periodically the implementation of this Convention by its States Parties" (art. 63, 4, e).

The monitoring process is to be understood as a long-term program that will need to be adapted to changing circumstances and the parties' learning progress. It must have a high rate of State Party participation and an efficient, properly resourced Secretariat. As part of this process, it is important to promote the collection and publication of information about anticorruption measures in the different countries, so as to add transparency to the various stages of the process. ${ }^{48}$ Realistic limits must be set as to what can be achieved (also from the point of view of the economic cost of monitoring). And the States Parties must build political support for the process (combining it, for example, with the technical assistance envisaged in the Convention) and exploit the synergies with the other monitoring instruments mentioned earlier. $^{49}$

\footnotetext{
${ }^{46}$ An example of this supervisory work is the "Mid-term study of phase 2 reports. Application of the Convention on Combating Bribery of Foreign Public Officials in International Business Transactions and the 1997 Recommendation on Combating Bribery in International Business Transactions”, Paris: OECD, Working Group on Bribery in International Business Transactions, May 22 ${ }^{\text {nd }}, 2006$.

47 Cf. Heimann (2005 a,b).

${ }^{48}$ It is important to establish a system of indicators that measure progress to date. See Argentina's proposal to the Preparatory Meeting of the Ad Hoc Committee for the Negotiation of a Convention against Corruption, A/AC.261/IPM/6, November $12^{\text {th }}, 2001$, no. 7 .

49 This is stated indirectly in art. 63, 4, d. There are various possible channels of coordination with, for example, the processes of the OECD, the Council of Europe or the Organization of American States: information exchange between the respective teams, specialization of each team in different areas, etc. In this connection, points in common between countries (language, culture, legal system, etc.) may facilitate regional monitoring - which would also facilitate acceptance of any recommendations that were made.
} 


\section{Conclusions}

The United Nations Convention against Corruption is an international instrument that has aroused interest and enthusiasm. If implemented successfully, it is likely to have a major impact on the prevention of and fight against corruption in the international arena, promoting national actions, creating a common framework and organizing cooperation among the States Parties. Furthermore, its approach and scope are ambitious; it has won the support of many countries in the drafting and signing phase (though only a small number of developed countries have actually ratified it so far); and it was negotiated on good terms, with intense United Nations involvement and in a short time. But it is only the first step in what should be a promising development. Its long-term success cannot be guaranteed, mainly because, at least for the time being, it lacks an effective mechanism to promote implementation and monitoring.

Insofar as it is effective, it will have a significant impact on companies, on a national level and worldwide, changing the framework in which they operate, making it clearer and more homogenous. It may also help to create an anti-corruption culture, involving not only governments, government agencies and public officials but, above all, companies and civil society. ${ }^{50}$

The Convention has some undoubted plus points, such as its condemnation of corruption, active and passive, public and private; the combination of prevention and criminalization; the emphasis on international cooperation and technical assistance, so that all countries are able to implement the Convention consistently and rigorously; and a viable mechanism for the return of the proceeds of corruption to their legitimate owner, or at least to their country of origin. ${ }^{51}$ But it also has its minus points, some of which have been pointed out in this article. Everything now will depend on how the Convention is implemented, although the scant interest shown by the developed countries in ratifying it casts a shadow of doubt over the likely outcome.

${ }^{50}$ Cf. Vlassis (2005).

51 Cf. "ICC views on the UN Convention against Corruption", 194/44, May 12 ${ }^{\text {th }}, 2005$, Babu (2006), Webb (2005). 


\section{Exhibit 1}

Main international legal instruments on corruption $^{52}$

\section{United Nations}

United Nations Convention on Transnational Organized Crime, Resolution 55/25 of November $15^{\text {th }}$, 2000. Signed by 147 countries; ratified by 122 countries (as of July $5^{\text {th }}, 2006$ ); came into force on September $29^{\text {th }}, 2003$ and requires corruption of public officials to be established as a criminal offence.

\section{Council of Europe}

Council of Europe Criminal Law Convention on Corruption, approved by the Committee of Ministers of the Council of Europe; opened to signing on January $27^{\text {th }}, 1999$. The Convention deals with the crimes of active and passive bribery of public officials, active and passive trading in influence, laundering of the proceeds of corruption, accounting crimes linked to corruption, active and passive bribery in the private sector, and facilitation and complicity in these crimes. The Group of States against Corruption (GRECO) monitors implementation of the Convention.

Civil Law Convention on Corruption of the Council of Europe, opened for signature by the Committee of Ministers of the Council of Europe on November $4^{\text {th }}, 1999$. This was the first attempt to define common international civil law rules on corruption.

\section{European Union (EU)}

Convention drawn up on the basis of Article K.3 of the Treaty on European Union (EU) on the protection of the European Communities' financial interests, adopted by the EU Council on July $26^{\text {th }}, 1995$. It deals with fraud affecting the European Union's financial interests.

Protocol drawn up on the basis of Article K.3 of the Treaty on European Union on the protection of the European Communities' financial interests, adopted by the EU Council on September $27^{\text {th }}$, 1996. It addresses, among others things, active and passive corruption involving national and Community officials that may damage the European Communities' financial interests.

Second Protocol drawn up on the basis of Article K.3 of the Treaty on European Union on the protection of the European Communities' financial interests, adopted by the Council on June $19^{\text {th }}, 1997$, addresses the issue of money laundering.

Convention drawn up on the basis of Article K.3 (2) (c) of the Treaty on European Union on the fight against corruption involving officials of the European Communities or officials of member States of the European Union, adopted by the EU Council on May $26^{\text {th }}, 1997$, deals with active and passive corruption of officials.

\footnotetext{
52 Cf. "Existing international legal instruments, recommendations and other documents addressing corruption. Report of the Secretary General". Economic and Social Council of the United Nations, E/CN.15/2001/3, April 2 $2^{\text {nd }}$, 2001. On some of these documents, cf. Corr and Lawler (1999), George et al. (2000), Low et al. (1998), Pacini et al. (2002),
} 


\section{Exhibit 1 (continued)}

Joint Action of December $22^{\text {nd }}$, 1998, adopted by the Council on the basis of Article K.3 of the Treaty on European Union on corruption in the private sector. Directed, in particular, at combating active and passive corruption in the private sector.

\section{Organization of American States (OAS)}

Inter-American Convention against Corruption, approved at a Special Inter-American Conference on March $29^{\text {th }}$, 1996, deals with corruption of national public officials, bribery of foreign public officials and illicit enrichment.

\section{Organization for Economic Cooperation and Development (OECD)}

Convention on Combating Bribery of Foreign Public Officials in International Business Transactions, signed on December $17^{\text {th }}, 1997$, addresses the issue of bribery of foreign public officials. This Convention and the Recommendation on Combating Bribery in International Business Transactions are monitored by the OECD Working Group on Bribery in International Business Transactions.

\section{African Union}

African Union Convention on Preventing and Combating Corruption and Related Offences, approved on July $12^{\text {th }}, 2003$. 


\section{Exhibit 2}

Other international documents on corruption ${ }^{53}$

\section{United Nations}

International Code of Conduct for Public Officials of December 1996, General Assembly, Resolution 51/59, annex. The Code deals with principles and recommendations for combating corruption.

United Nations Declaration against Corruption and Bribery in International Commercial Transactions, General Assembly Resolution 51/91, annex. Includes a set of measures that countries can implement to combat corruption.

Conclusions and Recommendations of the Expert Group Meeting on Corruption and its Financial Channels, Paris, March $30^{\text {th }}-$ April $1^{\text {st }}, 1999$, E/CN.15/1999/10. Measures to improve cooperation.

Action against corruption, General Assembly resolution 54/128. Suggests measures.

Report of the 10th United Nations Congress on the Prevention of Crime and the Treatment of Offenders, held in Vienna from April $10^{\text {th }}$ to $17^{\text {th }}$, 2000. Includes the Vienna Declaration on Crime and Justice: Meeting the Challenges of the Twenty-First Century, and the Report of the workshop on combating corruption.

Tenth principle of the United Nations Global Pact, proposed by the UN Secretary General on June $24^{\text {th }}, 2004$, at the first Global Pact Leaders Summit in New York. Contains certain principles that companies signing the Pact accept voluntarily.

\section{Council of Europe}

Twenty Guiding Principles for the Fight against Corruption, developed by the Multidisciplinary Group on Corruption and approved by the Committee of Ministers of the Council of Europe, Resolution (97) 24, on November $6^{\text {th }}$, 1997. These are fundamental directives that member States are called upon to implement in their efforts against corruption.

Model code of conduct for public officials, a recommendation adopted by the Committee of Ministers of the Council of Europe, on May $11^{\text {th }}, 2000$, includes recommendations and a model code.

\section{Organization for Economic Cooperation and Development (OECD)}

Revised Recommendation on Combating Bribery in International Business Transactions, adopted by the OECD Council on May $23^{\text {rd }}, 1997$, revising the 1994 Recommendation on Bribery in International Business Transactions.

\footnotetext{
53 Cf. "Existing international legal instruments, recommendations and other documents addressing corruption. Report of the Secretary General". Economic and Social Council of the United Nations, E/CN.15/2001/3, April 2 $2^{\text {nd }}$, 2001. 


\section{Exhibit 2 (continued)}

\section{Basel Committee on Banking Supervision}

Prevention of criminal use of the banking system for the purpose of money-laundering (1998). Guidance for financial institutions.

Core principles for effective banking supervision (1997) and Core principles methodology (1999). Guidance for banks.

\section{Financial Action Task Force on Money Laundering}

Forty recommendations, developed in 1990 and revised in 1996. The recommendations cover money laundering.

\section{Global Coalition for Africa}

Twenty-five principles to combat corruption, signed on February $23^{\text {rd }}$, 1999 by representatives of various African countries.

\section{Global Forum on Fighting Corruption}

Guiding principles, approved at the First Forum World against Corruption, held from to February $24^{\text {th }}$ to $26^{\text {th }}, 1999$ in Washington.

\section{Group of Eight}

Forty recommendations to combat transnational organized crime, prepared by a Senior Experts Group in April 1996.

\section{Asian Development Bank ${ }^{54}$}

Asian Development Bank - Organization for the Economic Cooperation and Development Anticorruption Initiative for Asia and the Pacific, adopted in Manila in October 1999. It includes recommendations and a voluntary government action plan. ${ }^{55}$

\footnotetext{
54 Cf. Asian Development Bank, “Anti-corruption Action Plan for Asia and the Pacific”, Tokyo, 2001.

55 "Technical Assistance for the Implementation of the ADB-OECD Anti-corruption Initiative for Asia and the Pacific”, Asian Development Bank, TAR:0TH 37476, November 2004.
} 


\section{Exhibit 3}

United Nations Convention against Corruption: Chapters and Articles' List

\section{Preamble}

\section{Chapter I: General provisions}

Art. 1. Statement of purpose

Art. 2. Use of terms

Art. 3. Scope of application

Art. 4. Protection of sovereignty

Chapter II: Preventive measures

Art. 5. Preventive anti-corruption policies and practices

Art. 6. Preventive anti-corruption body or bodies

Art. 7. Public sector

Art. 8. Codes of conduct for public officials

Art. 9. Public procurement and management of public finances

Art. 10. Public reporting

Art. 11. Measures related to the judiciary and prosecution services

Art. 12. Private sector

Art. 13. Participation of society

Art. 14. Measures to prevent money-laundering

\section{Chapter III: Criminalization and law enforcement}

Art. 15. Bribery of national public officials

Art. 16. Bribery of foreign public officials and officials of public international organizations

Art. 17. Embezzlement, misappropriation or other diversion of property by a public official

Art. 18. Trading in influence

Art. 19. Abuse of functions

Art. 20. Illicit enrichment

Art. 21. Bribery in the private sector

Art. 22. Embezzlement of property in the private sector

Art. 23. Laundry of proceeds of crime

Art. 24. Concealment

Art. 25. Obstruction of justice

Art. 26. Liability of legal persons

Art. 27. Participation and attempt

Art. 28. Knowledge, intention and purpose as elements of an offence

Art. 29. Statute of limitations

Art. 30. Prosecution, adjudication and sanctions

Art. 31. Freezing, seizure and confiscation

Art. 32. Protection of witnesses, experts and victims

Art. 33. Protection of reporting persons

Art. 34. Consequences of acts of corruption

Art. 35. Compensation for damage

Art. 36. Specialized authorities 


\section{Exhibit 3 (continued)}

Art. 37. Cooperation with law enforcement authorities

Art. 38. Cooperation between national authorities

Art. 39. Cooperation between national authorities and the private sector

Art. 40. Bank secrecy

Art. 41. Criminal record

Art. 42. Jurisdiction

\section{Chapter IV: International cooperation}

Art. 43. International cooperation

Art. 44. Extradition

Art. 45. Transfer of sentenced persons

Art. 46. Mutual legal assistance

Art. 47. Transfer of criminal proceedings

Art. 48. Law enforcement cooperation

Art. 49. Joint investigations

Art. 50. Special investigative techniques

\section{Chapter V: Asset recovery}

Art. 51. General provision

Art. 52. Prevention and detection of transfers of proceeds of crime

Art. 53. Measures for direct recovery of property

Art. 54. Mechanism for recovery of property through international cooperation in confiscation

Art. 55. International cooperation for purposes of confiscation

Art. 56. Special cooperation

Art. 57. Return and disposal of assets

Art. 58. Financial intelligence unit

Art. 59. Bilateral and multilateral agreements and arrangements

Chapter VI: Technical assistance and information exchange

Art. 60. Training and technical assistance

Art. 61. Collection, exchange and analysis of information on corruption

Art. 62. Other measures: implementation of the Convention through economic development and technical assistance

Chapter VII: Mechanisms for implementation

Art. 63. Conference of the States Parties to the Convention

Art. 64. Secretariat 


\section{Exhibit 3 (continued)}

Chapter VIII: Final provisions

Art. 65. Implementation of the Convention

Art. 66. Settlement of disputes

Art. 67. Signature, ratification, acceptance, approval and accession

Art. 68. Entry into force

Art. 69. Amendment

Art. 70. Denunciation

Art. 71. Depositary and languages 


\section{References}

Amundsen, I. (1999), "Political corruption: an introduction to the issues", Chr. Michelsen Institute Working Paper No. 7.

Argandoña, A. (2000), "Sobre la corrupción”, in Estudios de Comunicación y Derecho. Homenaje al profesor Manuel Fernández Areal, Editorial Compostela, Santiago, pp. 53-71.

Argandoña, A. (2001), "Corruption: the corporate perspective", Business Ethics. A European Review, 10 (2), pp. 163-175.

Argandoña, A. (2003a), "Political party funding and business corruption", in J. Wieland (ed.), "Standards and Audits for Ethics Management Systems. The European Perspective", Springer, Berlin, pp. 163-190.

Argandoña, A. (2003b), "Private-to-private corruption", Journal of Business Ethics, 47 (3), part II, pp. 253-267.

Babu, R.R. (2006), “The United Nations Convention against Corruption: a critical overview", Asian African Legal Consultative Organization, New Delhi.

Carlson, J. (2000), "Money laundering and corruption: two sides of the same coin", in "No Longer Business As Usual", Organization for Economic Cooperation and Development, Paris, pp. 127-136.

Corr, C. and J. Lawler (1999), “Damned if you do, damned if you don't? The OECD Convention and the globalization of anti-bribery measures", Vanderbilt Journal of Transnational Law, 32, pp. 1249-1344.

Elliott, K. (ed.) (1997), "Corruption and the Global Economy", Institute for International Economics, Washington, DC.

George, B.C., K.A. Lacey and J. Birmele (2000), “The 1998 OECD Convention: An impetus for worldwide changes in attitudes toward corruption in business transactions", American Business Law Journal, 37 (3), pp. 485-525.

Glynn, P., S. Kobrin and M. Naim (1997), "The globalization of corruption”, in K. Elliott (ed.), "Corruption and the Global Economy", (Institute for International Economics, Washington, DC, pp. 7-30.

Heimann, F. (2005a), "Follow-up monitoring needed for the UN Convention against Corruption", Compact Quarterly, 22, January.

Heimann, F. (2005b), "Making the United Nations Convention against Corruption work", in "Business against Corruption. Case stories and examples. Implementation of the 10th United Nations Global Compact Principle against Corruption”, Global Compact, New York, NY, pp. 1725. 
Jain, A. (ed.) (1998), “Economics of Corruption”, Kluwer Academic Publishers, Boston.

Low, L.A., A.K. Bjorklund and K.C. Atkinson (1998), "The Inter-American Convention against Corruption: a comparison with the United States Foreign Corrupt Practices Act”, Vanderbilt Journal of International Law, 38.

Michael, B. (2004), "What does the UN Convention on Corruption teach us about international regulatory harmonization?”, Linacre College.

Pacini, C., J.A. Swingen and H. Rogers (2002), "The role of the OECD and EU Conventions in combating bribery of foreign public officials", Journal of Business Ethics, 37 (4), part 1, pp. 385-405.

Posada, A. (2000), "Combating corruption under international law", Duke Journal of Comparative and International Law, 10 (2), pp. 345-414.

Quinones, E. (2000), "The promise and the reality of monitoring compliance with the Convention", in "No Longer Business As Usual", Organization for Economic Cooperation and Development, Paris, pp. 101-109.

Rose-Ackerman, S. (1997), "Corruption as an international policy problem: overview and recommendations", in K. Elliott (ed.), "Corruption and the Global Econom”, Institute for International Economics, Washington, DC, pp. 175-233.

Rose-Ackerman, S. (1999), "Corruption and Government: Causes, Consequences, and Reform", Cambridge University Press, Cambridge.

Tanzi, V. (1998), "Corruption around the World: causes, consequences, scope and cures”, IMF Staff Papers, 45 (4), pp. 559-594.

Vincke, F. and F. Heimann (eds.) (2003), "Fighting Corruption. A Corporate Practices Manual", International Chamber of Commerce, Paris, 2nd ed.

Vlassis, D. (2002), “The negotiation of the Draft United Nations Convention against Corruption”, Forum on Crime and Society, 2, 1.

Vlassis, D. (2005), "Why the UN Convention against Corruption matters to business", Compact Quarterly, 10, January.

Webb, P. (2005), “The United Nations Convention Against Corruption: global achievement or missed opportunity?”, Journal of International Economic Law, 8 (1), pp. 191-229. 